\title{
Classroom Contexts, Student Mindsets, and (In)Equity in Computer Science: A National Longitudinal Study
}

\author{
Ji Yong Cho ${ }^{1}$, Bharathy Premachandra ${ }^{2}$, Rene F. Kizilcec ${ }^{1}$, \& Neil A. Lewis, Jr. ${ }^{2,3}$ \\ ${ }^{1}$ Department of Information Science, Cornell University \\ ${ }^{2}$ Department of Communication, Cornell University \\ ${ }^{3}$ Department of Medicine, Division of General Internal Medicine, Weill Cornell Medicine
}

RUNNING HEAD: CONTEXTS, MINDSETS, AND LEARNING COMPUTER SCIENCE

\section{Author Note:}

The research reported in this manuscript was supported by funding from the Mindset Scholars Network and Bill \& Melinda Gates Foundation. The content is solely the responsibility of the authors and does not necessarily represent the views of the Mindset Scholars Network or the Bill \& Melinda Gates Foundation. This work was also supported by a Faculty Fellowship from the Cornell Center for the Social Sciences (N. A. Lewis, Jr). Correspondence concerning this article should be addressed to Rene Kizilcec (iilcec@ecornell.edu) or Neil Lewis, Jr (nlewisjr@cornell.edu). 


\begin{abstract}
The underrepresentation of women and racial minorities in computer science presents a challenge for training the next generation of scientists. The decision to pursue a professional and academic career in computing can be influenced by early experiences and mindsets in K-12 learning environments. However, we have a limited understanding of how student mindsets influence engagement in a variety of classroom contexts during high school computer science classes--one of the early gateways to computer science. We conducted a national longitudinal study of students in advanced placement computer science courses to understand how student mindsets impact engagement, how their mindsets evolve over time, and how contextual factors at the teacher, classroom, and school level can influence these temporal dynamics. We find that mindsets differentially impact engagement and vary by students' gender and status of racial underrepresentation. Some mindsets change over time due to course feedback, and these changes affect engagement and performance in different ways. Class characteristics (e.g., class size and female proportion) and school characteristics (e.g., proportion of students who are eligible for free lunch and proportion of racially underrepresented students) moderate the effect of mindsets on student outcomes. We discuss the implications of these findings for learning theories and equity-focused educational practices.
\end{abstract}

Keywords: STEM education, inequality, learning mindsets, heterogeneity 


\section{Classroom Contexts, Student Mindsets, and (In)Equity in Computer Science: A National Longitudinal Study}

A decade ago, the United States' President's Council of Advisors on Science and Technology argued that the U.S. needs to increase the number of students who study Science, Technology, Engineering, and Mathematics (STEM) (PCAST, 2012). This broad national goal has been plagued by several challenges, including under-enrollment and attrition among U.S. STEM students. For example, STEM disciplines like computer science have long struggled, and continue to struggle, to train and retain women and racial and ethnic minority students (Fry et al., 2021; Lord et al., 2011). The long-standing underrepresentation of women and racially minoritized individuals in the computing and information sciences presents economic and societal challenges. From an economic perspective, excluding entire demographic subsets of people who can meet labor market demands results in market inefficiencies. Further, excluding those who have insights and experiences in broader social contexts that have historically been excluded from the computing sciences undermines the field's ability to design products that meet the needs of a diverse group of consumers (Yarger et al., 2019). Overall, from a social welfare perspective, chronic underrepresentation of racial and ethnic minorities in computing undermines the nation's ability to reduce inequities that are related to bias in algorithms or the design of technology, because some issues are more likely to be noticed by people with marginalized identities (Lewis, in press; O’Neil, 2016; Ray, 2019). Homogeneity in educational contexts that are eventually tapped to supply the workforce can have detrimental effects at multiple levels over time, beyond just for those pushed to the sidelines.

The issue of underrepresentation in STEM education is tightly linked to student mindsets--how social contexts have led people to think about their experiences and whether they are relevant for their success and well-being in particular domains. 
Throughout K-12 education, female students, for example, are reported to develop mindsets that STEM fields are for males and thereby females may not belong there (Bian et al., 2017; Bian et al., 2018; Master et al., 2016). Female students' beliefs about STEM careers and their low sense of belonging are often pointed out to be one of the reasons why they avoid majoring in STEM in college (Makarova et al., 2019; Cundiff et al., 2013). Early research on learning mindsets also examined the link between individual mindsets and academic performance (e.g., Dweck, 2006; Walton \& Cohen, 2011; Yeager et al., 2016). Female and racially minoritized students who are concerned about being negatively judged by peers and instructors for their qualification and intelligence tend to underperform in STEM courses compared to their counterparts $\left(\mathrm{O}^{\prime}\right.$ Brien et al., 2015). Low academic performance makes students less competitive in the job market, which limits the chances of being hired and potentially abandoning pursuing STEM careers.

Previous research suggests that students' mindsets can be shaped by features of the learning environment. The design of classrooms (e.g., wall decorations) influences how much students feel they belong in a class (i.e., sense of belonging) and further how much they want to engage in the class (e.g., class enrollment) in physical spaces (Cheryan et al., 2009; Cheryan \& Markus, 2020; Murphy et al., 2007) as well as in online spaces (Kizilcec \& Saltarelli, 2019; Kizilcec et al., 2020). More broadly, countries students are in and neighborhoods they live in affect learning attitudes due to the structural affordances and cultural features of those countries (Kizilcec et al., 2017). In countries like the U.S., which have large regional and district-level differences, the neighborhoods in which schools are located also matter for what students learn and how they learn it (Lewis \& Yates, 2019; Oyserman \& Lewis, 2017).

Moreover, students' socioeconomic backgrounds also affect their learning experiences and further their attitudes towards learning (i.e., mindsets). Because geographic differences affect 
how people from different backgrounds are socialized in the U.S. (Lewis, in press), student demographic characteristics--like their gender, race and ethnicity, socioeconomic status--also shape student experiences in classrooms and occupy their thoughts when it is time for them to learn (Destin et al., 2019; Fisher et al., 2017; Fisher \& Oyserman, 2017; Kizilcec \& Saltarelli, 2019; Miller-Cotto \& Lewis, 2020; Walton \& Cohen, 2011).

Two streams of research have been conducted in parallel on students' experiences and academic achievement. While research in economics and sociology has examined effects of macro-level contexts, such as college admission policies and access to high-quality education, on student achievement (Dynarski et al., 2018; Heckman \& Karapakula, 2019), research in psychology has examined effects of micro-level interventions, such as fostering individual students' growth mindsets (Yeager et al., 2016). However, fewer studies have examined the joint effects of broader macro-level contextual variables and micro-level psychological processes on students' experiences and outcomes, and how those joint processes unfold over time (i.e., in longitudinal studies) in ecologically valid settings. This gap in the literature limits our ability to build holistic theories that can generate predictions about the conditions under which psychological processes matter for student achievement (see Bryan et al., 2021). It also limits our ability to apply those theories to improve student experiences and outcomes (c.f., IJzerman et al., 2020).

Given these gaps in the literature, as well as the problem of gender and racial inequity in computer science, we investigated what factors matter most in this domain. Which individual and contextual factors matter for student outcomes--and inequities in outcomes--in the context of high school computer science? To learn about the heterogeneous learning processes in this educational context, we partnered with a computer science education organization to study how 
these dynamics unfold for the diverse set of students their curriculum serves all across the United States.

\section{Current Study}

\section{Research-Practice Partnership}

This study was done in collaboration with Code.org during the 2017/2018 school year. Code.org is a non-profit organization dedicated to increasing computer science access in schools, with a particular focus on increasing engagement among women and students from underrepresented racial minority groups. Code.org partnered with high schools across the United States to offer an Advanced Placement Computer Science course, which was deployed in 11,677 classrooms from 3,216 schools via 6,346 high school teachers who taught it to over 83,621 students. We worked with Code.org to embed surveys into their curriculum throughout the year to measure how students' mindsets changed while taking the course. This allowed us to examine the relationships between student demographics, their mindsets, and course outcomes within an ecologically valid course environment.

\section{Study Design and Research Questions}

The AP computer science course consisted of five learning units, which contained lessons broken down into multiple levels. Students' mindsets were measured in the first unit (pre-survey), at the end of the third unit (mid-survey), and at the end of the fifth unit (post-survey). The three surveys, for the most part, asked identical questions (verb tense was changed to reflect the different time points). For consistency, we only used survey items that were included at all three-time points and that were relevant to our research questions. To analyze the relationships between students' mindset and their learning outcomes, we grouped student performance data into two time periods: time period 1 i.e., T1 (after pre-survey and 
before mid-survey) and time period 2 i.e., T2 ( after mid-survey and before post-survey), as shown in figure 1.

[Figure 1]

This study design allowed us to investigate the following three research questions, which we pre-registered on the Open Science Framework (https://osf.io/zgd3j/):

RQ1. How do students' pre-existing mindsets at the beginning of the course influence their engagement with the first set of course learning materials they encounter (T1)?

RQ2. Does early feedback in the course (i.e., performance at T1) change students' mindsets mid-course, and do those changes in mindsets affect subsequent engagement with learning materials and subsequent performance later in the course (T2)?

RQ3. To what extent are the pathways outlined in RQ1 and RQ2 moderated by student characteristics, class characteristics, school characteristics?

\section{Measures}

\section{Demographic \& School Characteristics}

From Code.org, we obtained multi-level demographic information for students (age, gender, and URM status), teachers (gender and URM status), classrooms (class size, female student ratio, and URM student ratio), and schools (school size, the locale of school, URM student ratio, free lunch recipient ratio, and the presence of high school instruction). All of the classroom variables were calculated by the authors using information available for students. The URM status variable provided for both students and teachers captured racial minoritization as a binary, racial minority $(U R M)$ or non-racial minority (non- $U R M)$, but not broken down by specific racial or ethnic groups. Students who are "Black / African American, Hispanic/Latino/Latina/Latinx, Native American/Alaskan, and Native Hawaiian/Pacific 
Islanders" were categorized as URM by Code.org since 2016 (Code.org 2019 Annual Report, n.d.). Information provided about sex for both students and teachers was limited to binary options male and female.

\section{Student mindset surveys}

The student mindset surveys measured different aspects of the student's psychological experience over three points in time, i.e., at the beginning (pre), midpoint (mid), and end of the course (post). The survey items were adapted from established measures and curated to be brief to increase the likelihood of responses from students who saw the surveys embedded in-between units of their AP course materials. Appendix A provides descriptive statistics for each survey measure, inter-correlations, and the proportion of missing values.

Sense of Belonging. (Cronbach's a pre $=.83$; a mid $=.84$; a post $=.83$ ). To assess students' sense of belonging in the classroom, students were asked about the extent to which they agreed with eight statements adapted from Walton and Cohen (2011) on a scale from (0) strongly disagree to (6) strongly agree. The statements included "I feel like I can be myself in this computer science class" (see Appendix A for the full list of statements).

Personal Relevance. (Cronbach's a pre $=.90 ; \mathrm{a}$ mid $=.91$; $\mathrm{a}$ post $=.91$ ). To assess the extent to which students considered computer science to be relevant for their future goals, students were asked about the extent to which they agreed with the following three statements adapted from Beyer (2014) on a scale from (1) strongly disagree to (7) strongly agree:

"Computer science is important for my future"; "I expect that I will use computer science in my job"; and "I want to take more computer science classes in the future.".

\footnotetext{
${ }^{1}$ As of September 2020, in the interest of inclusivity, Code.org has committed to discontinue the use of the term 'underrepresented minorities' and provide disaggregated data when measuring access gaps when possible (Using More Inclusive Language at Code.org, n.d.).
} 
Stereotype Threat Concerns. (Cronbach's a pre $=.68$; a mid $=.79$; a post $=.79$ ). To assess whether students were concerned about being judged in line with negative stereotypes about their groups, students were asked to rate two statements adapted from Cohen and Garcia (2005) on a scale from (0) not at all to (2) a lot: "I worry because of my gender" and "I worry because of my race/ethnicity."

Worries About Math Ability. To assess whether students were worried that their math abilities might hinder their performance in computer science, students rated the following statement on a scale from (0) not at all to (2) a lot: "I worry because I'm not good at math."

Worries about previous experiences with computer science. To assess the extent to which students worried that their lack of experience with computer science might hinder their performance in the computer science class, students rated the following statement on a scale from (0) not at all to (2) a lot: "I worry because I have little experience with computer science."

Lay Theories of Intellectual Abilities. To assess students' beliefs about people's ability to learn computer science, students rated two statements on a scale from (0) strongly disagree to (6) strongly agree: "Some people are just better at learning and doing computer science than others" (labeled innate ability in the analysis) and "Every person has the same ability to learn computer science, no matter their gender, skin color, or background" (labeled universal ability in the analysis).

\section{Student course outcomes}

Engagement. Student engagement during the course was measured by the total number of unique levels attempted by the student on the Code.org platform. Levels are the smallest unit of the five main learning units in the course materials and therefore provide the most fine-grained measure of student engagement. For example, the first unit in the course ("The 
Internet") contains 14 lessons taught over five weeks and each lesson contains at least five levels (the course syllabus is available online at https://curriculum.code.org/csp-1718/). In the focal sample (defined below), students studied an average of 3.77 units, 40.6 lessons, and 257 levels in the course. The average number of levels students attempted was 147 and 214 in time period T1 and $\mathrm{T} 2$, respectively.

Performance. Each level contained several assessment questions which included automatically graded multiple-choice, short-answer, and programming questions. Most questions in the course were formative assessments that allow students to re-attempt the question until they get the correct answer. The average proportion of correct responses on the first attempt on the assessment questions was used to measure student performance. We calculated the proportion of the number of questions answered correctly in the first attempt out of the questions attempted across levels. In the focal sample, the average proportion of correct responses in period T1 and T2 was .22 and .17, respectively. Performance in period T1 was operationalized as early feedback to students in RQ2.

\section{Data Cleaning}

\section{Focal Sample Definition}

Our objective in defining a focal sample for the analysis was to systematically reduce the proportion of missing values while retaining a large and representative data set (Jakobsen et al., 2017). We expected missing values to be clustered by classrooms and teachers because some classrooms in the data set are unrealistically large (hundreds of students) or small (one or two students), and data entry for student and teacher demographic characteristics was centralized within schools. To focus on classrooms with a reasonable number of students, we excluded data for classrooms that fall outside of the 9 to 61 student range, which also had the lowest 
proportions of missing data. To focus on students whose teachers encouraged demographic data entry and survey completion on the platform, we excluded all data associated with teachers where more than $50 \%$ of their students' data on gender, URM status, and survey responses were missing. For students who were associated with multiple classrooms, we randomly selected one datapoint for inclusion in the focal sample. The focal sample consisted of 7,142 students taught in 364 classrooms by 247 teachers across 227 schools. Table 1 provides descriptive statistics for the focal sample and the proportion of missing values.

\section{Multiple Imputation and Pooled Analysis}

Due to missing demographic and survey information for some students, multiple imputation was conducted. The proportion of missing data in the focal sample is shown in Table 1. Prior to data imputation, we calculated student outcome variables and class-level variables with the focal sample dataset. Student engagement and performance were computed from the Code.org platform data, resulting in a complete dataset with no missing values. Similarly, class-level data, including class size and the proportion of female and URM students were calculated from the original data excluding missing values, which simplified the analysis and yielded nearly identical estimates as calculating them from the imputed datasets (Pearson correlation: $r(358)=.99, \mathrm{p}<.0001)$.

We followed recommendations for addressing missingness in longitudinal educational data (Coertjens et al., 2017; Manly \& Wells, 2015; Peugh \& Enders, 2004). Specifically, we generated multiple imputation data sets using the mice $\mathrm{R}$ package (Buuren \& Groothuis-Oudshoorn, 2010). Predictive mean matching, log-linear regression, polytomous regression, and a proportional odds model were applied to the available data to impute missing values on continuous (student age, survey items), binary (student gender, student URM, presence 
of high school unit), unordered categorical (locale of school), and ordered categorical variables (school size), respectively. A total of 59 variables (51 survey items, 3 student characteristics, and 5 school characteristics) were imputed. Class characteristics, student engagement, and performance were included in the model estimation but were not imputed. Further, we did not impute teacher characteristics due to the high rate of missing values for these variables (above 90\% missing). We excluded teacher characteristics from the imputation model and further analysis. We created 15 imputed datasets, using 20 iterations to generate each imputation.

Analysis of multiply imputed data is performed by running the same model on each of the 15 imputed datasets separately and then combining the model estimates. We used the pool function in the Mice R package, which computes between- and within-dataset variances following the Barnard and Rubin pooling estimator equations (Barnard, 1999; Rubin, 2009). The protocol and analysis plan for this study was pre-registered with the Open Science Framework (OSF) on 10 December 2020. The pre-registration, analysis code, and results are available on the OSF (https://osf.io/zgd3j/). Below, we explain our analytic approach for each research question.

\section{[Insert Table 1]}

\section{Analytic Approach}

Our first research question is how students' pre-existing mindsets at the beginning of the course influence their engagement with the first set of course learning materials they encounter (T1). We use a linear regression model predicting T1 student engagement with teachers as fixed effects and student characteristics, class characteristics, and school characteristics as covariates. Student mindsets were added as predictors into the regression model altogether (one regression) and individually (seven regressions). We also predicted individual pre-existing mindsets with 
student gender, URM status, and the interaction between student gender and URM status (seven regressions).

Our second research question is whether early feedback in the course (i.e. answering questions on early assignments correctly or incorrectly) changes students' mindsets mid-course and whether those changes in mindsets affect subsequent engagement with learning materials and subsequent performance later in the course (T2). We used two linear regression models for each mindset variable with teacher fixed effects and student characteristics, class characteristics, and school characteristics as covariates. The first regression model predicts the change in a student mindset (from pre- to mid-survey) with T1 performance as a proxy for feedback. The second regression model predicts T2 performance with the pre- to mid-survey change in a student mindset and including T1 performance as another covariate. We therefore fitted a total of 16 linear regression models: eight mindsets with two model specifications each.

Our third research question is to what extent the pathways outlined in RQ1 and RQ2 are moderated by student characteristics, class characteristics, and school characteristics. A principled approach is needed to identify moderators among the large set of combinations of mindsets and characteristics. We concatenated the fifteen imputed datasets into one large dataset and ran stepwise regression on the combined dataset to find the most likely moderators for further analysis using the step function in the stats R package. This function tests multiple regression models containing combinations of variables and suggests a regression model with the best model fit in terms of the Akaike Information Criterion (AIC). Specifically, it takes two models, a base model that contains the minimum set of variables and a full model that contains the maximum set of variables, and adds variables one by one to the base model until it reaches the full model specification. In the present study, the base model does not include interactions 
between mindsets and characteristics variables, but the full model includes all possible interactions. We expected the student characteristics, class characteristics, school characteristics variables from the interaction terms in the final model would serve as moderators. Finally, we verified the suggested moderators by checking if interactions were significant in a pooled analysis, using the Mice R package.

\section{Results}

\section{Predictors of Student Engagement}

To examine how student demographics and mindsets are related to their engagement in the course, we fit a regression model of engagement in the first half of the course with all mindset variables and covariates as predictors (Table 2). The results show that male students engaged with fewer course materials than female students, and URM students engaged with fewer course materials than non-URM students. Moreover, students' mindsets coming into the course predict their engagement with course materials during the first half of the course (RQ1). Specifically, students who came in viewing the course as more relevant for their future (personal relevance) were more engaged with the course material, as were those who were initially worried about their lack of prior computer science experience (worries about $C S$ ) and those who believed that some are better at learning and doing computer science than others (innate ability). On the other hand, students who were worried about their math competency (worries about math) and those who were worried about others perceiving their computer science ability being tied to "gender, skin color, or background" (stereotype threat) were less engaged with the course content. Students' pre-existing expectations of class belonging (belonging) and beliefs that everyone can succeed in learning computer science (universal ability) were not significant predictors of their level of engagement. 
[Insert Table 2]

\section{Demographic Correlates of Student Mindsets}

To examine patterned variation in mindsets across students, we analyzed whether gender and URM status predict students' mindsets at the start of the course. As shown in Table 3, we found that female students started the course with significantly lower expectations of classroom belonging (belonging) and they found the course less relevant to their future (personal relevance) compared to male students. Similarly, URM students also showed a lower sense of belonging in the course (belonging) and lower relevance to the course (personal relevance) compared to non-URM students. While female students were more worried than male students about their lack of experience in computer science (worries about CS) and that their gender/race would negatively influence how others perceive their capability for computer science (stereotype threat), URM students were more worried than non-URM students about their lack of experience in math (worries about math). Female students were more likely than male students to think that computer science ability was something universal (universal ability).

[Insert Table 3]

\section{Changes in Student Mindsets Related to Early Feedback}

We examine next whether the feedback that students received on their early performance in the course (T1) would influence changes in their mindsets between periods T1 and T2 (RQ2). Of the mindsets we measured, only the change in personal relevance was related to early feedback; students who performed better at the beginning of the course became more convinced that the course was relevant to their future than they were at the beginning of the course ( $b=.26, t(117.5)=3.41, p=.0009)$. No other mindsets were affected by early feedback (belonging: $b=.10, t(279.5)=1.69, p=.09 ;$ stereotype threat; worries about math: 
$b=.05, t(100.9)=1.41, p=.16 ;$ worries about $C S: b=-.01, t(142.6)=-.30, p=.77$

; innate ability: $b=.06, t(125.9)=.63, p=.53$; universal ability:

$b=-.04, t(250.7)=-.44, p=.66)$.

\section{Subsequent Engagement and Performance Related to Changes in Student Mindsets}

We further examine the extent to which changes in student mindsets are associated with their engagement and performance in the second half of the course (period T2). We found that a stronger sense of personal relevance increased engagement (personal relevance:

$b=1.99, t(79.8)=2.10, p=.04)$, while increased worries about having less experience with CS decreased engagement (worries about CS:b=-4.45, $t(118.1)=-3.16, p=.002$ ). Changes in other mindsets were not significantly associated with engagement in the second half of the course (belonging: $b=.32, t(96.7)=.28, p=.78$; stereotype threat:

$b=2.66, t(46.5)=.91, p=.37$; worries about math: $b=.74, t(101.4)=.41, p=.68$;

innate ability: $b=.33, t(79.7)=.49, p=.62$; universal ability:

$b=.31, t(93.6)=.44, p=.66)$.

Student performance in the second half of the course was associated with a change in only one student mindset: an increased sense of belonging significantly enhanced performance in period T2 (belonging: $b=.01, t(218.8)=2.78, p=.006)$. Other mindset changes were not significantly related to performance in period T2 (personal relevance:

$b=.003, t(201.4)=1.09, p=.28 ;$ stereotype threat:

$b=0.004, t(178.8)=.50, p=.62 ;$ worries about math:

$b=.002, t(157.1)=.41, p=.68$; worries about $C S: b=.001, t(82.9)=.30, p=.76$;

innate ability: $b=.001, t(117.7)=.60, p=.62$; universal ability:

$b=-.001, t(139.4)=-.47, p=.64)$. 


\section{Moderators of Student Trajectories}

Finally, we investigate which student-level, class-level, and school-level characteristics moderate the influence of mindsets on student outcomes as described in the first two research questions (RQ3). We identified five significant moderators of the effects of mindsets at the start of the course on engagement in period T1 (Figure 2).

First, the effect of students' initial sense of belonging on engagement in period T1 was moderated by community type (e.g., suburban relative to city schools:

$b=-3.41, t(263.9)=-2.59, p=.01)$. Students' sense of belonging in schools located in suburban areas was less predictive of engagement than for students in schools located in other types of communities such as in cities.

Second, worries about stereotype threat had a more positive effect on engagement in period T1 for students from schools with fewer URM students ( $b=-22.24, t(141.0)=-2.31, p=.02)$. When stereotype threat increases, their engagement increases for students from schools with a lower proportion of URM students (e.g., $1 \%$, which is $1 \mathrm{SD}$ below the mean, $32 \%$ ). The lower the URM proportion in the school, the more students engage when they experience stereotype threat. In contrast, students from schools with a higher URM students proportion (e.g., $62 \%$, which is $1 \mathrm{SD}$ above the mean) engage less when they experience stereotype threat.

Third, the positive effect of perceived relevance on engagement in period T1 was moderated by the proportion of free-lunch eligible students at the school ( $b=-4.97, t(267.0)=-2.09, p=.04)$, such that in schools with more free-lunch eligible students, the positive effect of perceived relevance was attenuated. Thus, for students in schools serving a large proportion of students from low-income families, their sense of personal 
relevance does not contribute to engagement as much as for students in high-income schools.

Fourth, the negative effect of worries about math on engagement in period T1 was attenuated in classes with a higher proportion of female students ( $b=14.29, t(873.7)=3.10, p=.002)$. In classrooms with a relatively lower female students proportion (e.g., 13\%, which is $1 \mathrm{SD}$ below the mean) students are more engaged when they are not worried about math. On the other hand, students in a class with a higher female student proportion (e.g., 45\%, which is $1 \mathrm{SD}$ above the mean) engage more when they are worried about math.

And fifth, the negative effect of worrying about being less experienced in CS on engagement was attenuated in larger classes $(b=-.15, t(569.2)=-2.03, p=.04)$. In smaller classes, the more students worried about their prior CS experience, the more they engaged with the materials. However, this effect was diluted in larger classes.

Finally, we did not find any significant moderators of the effect of early feedback on changes in student mindset (pre- to mid-survey) or of the effect of mindset changes on engagement or performance in period T2, as described in the second research question.

[Figure 2]

\section{General Discussion}

\section{Summary of Findings}

The study reveals significant gender and racial differences in students' mindsets coming into the course, their engagement with course materials, and how mindsets influence engagement. Specifically, we found that female students and URM students start off with lower expectations of classroom belonging, lower sense of personal relevance of the course. Female students are also more concerned about being underprepared and viewed as less capable in 
computer science, while URM students worry about being less experienced in math.

Our study also reveals a number of contextual features at the class level (e.g., class size, class female proportion) and the school level (e.g., school free lunch proportion, school URM proportion, community type) that moderate how certain mindsets affect student engagement in the first half of the course. We now discuss our findings for each contextual factor that was a significant moderator:

\section{Class Size}

In a smaller class, worrying about one's lack of experience in CS was associated with increased student engagement. Students may engage more in smaller classes to avoid the appearance of being incapable given the increased likelihood of being noticed in a smaller class. Moreover, their peers may participate in class activities more actively and teachers tend to interact more with students in a smaller class (Finn et al., 2003).

\section{Share of Female Students in the Class}

Students who enter the course worried about their math abilities are more engaged if the class is gender-balanced rather than male-dominated. This trend holds for both female and male students. We suspect that female students who worry about math are more likely to associate their worries with the stereotype that women are not good at math (Kiefer \& Sekaquaptewa, 2007), which is known to have adverse effects on academic engagement and achievement for women (Spencer et al., 1999; Nosek et al, 2002). Male students in classes with a higher proportion of female students tend to engage more despite increased worries about their CS experience. This may be because the negative stereotype associated with women's math competency provides a basis for male students to believe that they need to perform better (Walton \& Cohen, 2003; Shih et al., 20002). This may especially be the case in a classroom 
setting with more female students where the need to maintain their perceived gender-based advantage is seen as pressing (Swan \& Wyer Jr, 1997).

\section{Community Type}

Students who feel more belonging in the class tend to be more engaged in all types of communities. This effect of belonging on engagement, however, is smaller for students in suburban areas compared to those in urban and rural areas. Schools in suburban areas are more advantaged than schools in urban and rural areas in terms of poverty and overall levels of academic proficiencies in reading and math (Logan \& Burdick-Will, 2017) and the largest proportion of the best $25 \%$ of public high schools are located in suburban areas (Moody, 2021). Students may already feel more belonging by virtue of being in the supportive context of a highly resourced school (Howard, 2013). The environment may act as a structural motivator that possibly drives engagement, leaving less room for belonging to act as a psychological motivator of engagement (Faircloth \& Hamm, 2005; O'Keeffe, 2013; Hausmann et al., 2009).

\section{Share of Free Lunch Eligible Students in the School}

Students are more engaged when the course is personally relevant to them, but the strength of this relationship depends on the share of free lunch eligible students at the school. In schools with few free lunch eligible students, which tend to be richer schools or schools with a small proportion of students from low-income families (Harwell \& LeBeau, 2010), students engage not as much when they find the course is not personally relevant to them. Personal relevance appears to be more critical to course engagement for students from richer schools. Students with the lowest sense of personal relevance and in schools with the fewest free lunch eligible population were the least engaged in the course. These students may strategically choose to engage less in the course because they think the course is not relevant to their future academic 
and career plans. In fact, the statements students rate for the personal relevance survey measure capture their clarity of knowing their future plans and the path to get there. Students from advantaged backgrounds attending well-resourced schools may have more access to opportunities and knowledge that increases their readiness for academic and career pathways (Jack, 2016; Lareau, 2015).

\section{Share of URM students in the School}

Stereotype threat has a surprisingly positive effect on student engagement in schools with a lower share of URM students. In schools with nearly no URM students $(1 \%$, which is one standard deviation below the mean), stereotype threat increases engagement, while in schools with a majority of URM students (62\%, one SD above the mean), stereotype threat slightly reduces engagement. Schools with a higher proportion of URM students are often at a structural disadvantage in terms of funding and resources, including hiring qualified teachers (Loeb et al., 2005). Top high schools tend to have an underrepresentation of minoritized students in their student body, typically making up no more than a quarter of its population (Moody, 2021). Assuming that the schools with lower URM proportions are better resourced and more likely to fall under the 'higher achieving' or 'elite' category, there is an increased likelihood of competition and pressure to perform well (Luthar \& Kumar, 2018; Luthar, Kumar \& Ziillmer, 2020; Ebbert, Kumar \& Luthar, 2019). In such an environment, students are more susceptible to stereotype threats such that they engage more to avoid being perceived as less capable (Steele \& Aronson, 1995).

Beyond the discovery of several important contextual moderators that shape how mindsets influence student outcomes, this study is one of the first to reveal the temporal dynamics of student mindsets, engagement, and performance in context. Students who perform 
highly early in the course believe that the course is even more relevant to them later in the course. The increased sense of relevance also increases course engagement over time. However, increased worries about CS negatively impact later course engagement. We also found that an increased sense of belonging increases student performance. There was no evidence to suggest that class-level or school-level factors moderate these temporal changes between mindsets, engagement, and performance. Overall, given that AP computer science acts as a gateway for students into computing majors and selective colleges, we expect our findings for course engagement and performance to have longer-term consequences for students' academic and professional careers, including whether they choose to work in the area of computing.

\section{Limitations and Future Research}

The present study offers novel insights into the temporal dynamics of student mindsets and behavioral outcomes in the context of an AP computer science course offered across the United States. However, the research also presents several limitations. First, although we investigate a relatively large number of mindsets, we do not examine social support factors (e.g., peer interactions and teacher interactions) which have been associated with positive student outcomes in a variety of educational contexts (Wilcox et al., 2005; Russell, 2017). Our dataset provides a detailed account of school-level factors, such as free lunch eligibility, community type, but it offers little insight into social support structures that may also interact with student mindsets over time. Future research can advance our understanding of these dynamics by including social support indicators that capture the students' social experience.

Second, our analysis of how early feedback shapes student mindsets relied on performance feedback provided automatically on quiz attempts by the interactive learning environment. However, this is one out of many sources of feedback that students receive and 
future research in this area can further advance our understanding of how feedback shapes mindset by including other forms of feedback (e.g., in-class grades, teacher comments) in the analysis.

Third, while we planned to use teacher-level information to understand how student mindsets might be affected by teacher characteristics in computer science, this information was missing for around $90 \%$ of observations, which limited our ability to do that analysis. However, prior research has shown that instructors with a minoritized background in computer science (e.g., female and URM teachers) can act as role models for students with the same background (Bottia et al., 2015; Price, 2010). This presents an important opportunity for future research to examine how teacher characteristics affect students during formative computer science experiences in the classroom.

Lastly, relative to the national distribution of school community types, our dataset overrepresented suburban schools and underrepresents rural and town schools. ${ }^{2}$ This selection bias can affect the validity of the inferences we draw given that suburban schools may have better access to resources (Hansen, 2014), but it also reflects the present state of access to computer science education. According to the US national assessment of educational progress survey, among the different school community types, high school students in suburban areas had the highest percentage of access to computers at home in the school year 2015-6 (NAEP, 2018). Future research might measure computer access at the student, class, and school level to better capture access-related heterogeneity in student outcomes, which is especially relevant in CS education, which requires more practice and hands-on learning (Barr \& Stephenson, 2011; Wang

\footnotetext{
${ }^{2}$ Our imputed dataset has around $51 \%$ of students from suburban schools, however, according to the public elementary and secondary education report for the school year 2015-16 released by NCES, students from suburban areas make up around $39 \%$ of the student population. See https://nces.ed.gov/pubs2018/2018052/tables/table_04.asp.
} 
et al., 2016; Kafai et al., 2014).

\section{Implications for theory}

The findings of this research contribute to theory in the interdisciplinary learning sciences that focus on how characteristics of learning environments (Kizilcec \& Kambhampaty, 2020), students' mindsets (Yeager et al., 2019) and contextual characteristics, such as norms, social support, and accessibility to resources (Lewis \& Yates, 2019; Yeager et al., 2019) combine to influence student academic engagement and performance. Early research on learning mindsets often examined links between individual mindsets and academic performance (Walton \& Cohen, 2011; Yeager et al., 2016). Researchers have documented since then that there is substantial heterogeneity in the effects of mindsets on student engagement and performance (Bryan et al., 2021). To understand the nature of this heterogeneity and advance the theory of mindsets in context requires studying multiple mindsets simultaneously in real-world environments; this work provides insights into how learning dynamics unfold over time in the contexts in which students are embedded.

Following this approach in the current study, we learned that students' engagement and performance in AP computer science are shaped by their pre-existing mindsets which are related to their social identities. These results are consistent with identity-based motivation theory, a social psychological theory of human motivation and goal pursuit that explains when people's identities and social contexts motivate them to take action in pursuit of their goals (Oyserman et al., 2017). Students' gender and racial identities shaped their early experiences in this course, such as how much they engaged with course materials, as well as their responses to feedback in the course. Previous research on identity-based motivation has documented that when students learn in contexts that marginalize their identities, it undermines their academic engagement and 
performance (Oyserman \& Lewis, 2017). In this study, we found evidence to suggest that there is also a positive and productive side of this effect. If the nature of a class leads students to believe that the content is relevant to their identities, then it can have a positive effect on their engagement and performance, especially for minoritized students who have the opportunity to learn in schools where there are more people like themselves.

\section{Implications for practice}

Our findings offer guidance to policymakers and behavioral scientists who are working to improve the underrepresentation of women and racial minorities in computing fields. Middle and high school administrators and teachers have an opportunity to shape those student mindsets that eventually influence their decision to sign up for AP computer science and persist in the course, especially for female and URM students. While several mindsets are predictive of student outcomes, the one that stands out as having longer-term effects is students' sense of personal relevance to the course materials and worries about the lack of experience in CS. This suggests an opportunity for early intervention to help students realize the potential utility value of academic training in computing (Hulleman et al., 2010) and see any perceived lack of CS experience as a learning opportunity and not an obstacle (Zepeda et al., 2020). 


\section{References}

Barnard, J. (1999). Miscellanea. Small-sample degrees of freedom with multiple imputation. In Biometrika (Vol. 86, Issue 4, pp. 948-955). https://doi.org/10.1093/biomet/86.4.948

Barr, V., \& Stephenson, C. (2011). Bringing computational thinking to K-12: what is Involved and what is the role of the computer science education community?. Acm Inroads, 2(1), $48-54$.

Bottia, M. C., Stearns, E., Mickelson, R. A., Moller, S., \& Valentino, L. (2015). Growing the roots of STEM majors: Female math and science high school faculty and the participation of students in STEM. Economics of Education Review, 45, 14-27.

Bian, L., Leslie, S.-J., \& Cimpian, A. (2017). Gender stereotypes about intellectual ability emerge early and influence children's interests. In Science (Vol. 355, Issue 6323, pp. 389-391). https://doi.org/10.1126/science.aah6524

Bian, L., Leslie, S.-J., Murphy, M. C., \& Cimpian, A. (2018). Messages about brilliance undermine women's interest in educational and professional opportunities. In Journal of Experimental Social Psychology (Vol. 76, pp. 404-420). https://doi.org/10.1016/j.jesp.2017.11.006

Bryan, C. J., Tipton, E., \& Yeager, D. S. (2021). To change the world, behavioral intervention research will need to get serious about heterogeneity. Nature Human Behaviour.

Cheryan, S., \& Markus, H. R. (2020). Masculine defaults: Identifying and mitigating hidden cultural biases. Psychological Review, 127(6), 1022-1052.

Cheryan, S., Plaut, V. C., Davies, P. G., \& Steele, C. M. (2009). Ambient belonging: how stereotypical cues impact gender participation in computer science. Journal of Personality and Social Psychology, 97(6), 1045-1060. 
Code.org 2019 Annual Report. (n.d.). Retrieved May 31, 2021, from https://code.org/about/2019

Coertjens, L., Donche, V., De Maeyer, S., Vanthournout, G., \& Van Petegem, P. (2017). To what degree does the missing-data technique influence the estimated growth in learning strategies over time? A tutorial example of sensitivity analysis for longitudinal data. In PLOS ONE (Vol. 12, Issue 9, p. e0182615). https://doi.org/10.1371/journal.pone.0182615

Cundiff, J. L., Vescio, T. K., Loken, E., \& Lo, L. (2013). Do gender-science stereotypes predict science identification and science career aspirations among undergraduate science majors? Social Psychology of Education, 16(4), 541-554.

https://doi.org/10.1007/s11218-013-9232-8

Destin, M., Hanselman, P., Buontempo, J., Tipton, E., \& Yeager, D. S. (2019). Do Student Mindsets Differ by Socioeconomic Status and Explain Disparities in Academic Achievement in the United States? AERA Open, 5(3). https://doi.org/10.1177/2332858419857706

Dynarski, S., Libassi, C. J., Michelmore, K., \& Owen, S. (2018). Closing the Gap: The Effect of a Targeted, Tuition-Free Promise on College Choices of High-Achieving, Low-Income Students. https://doi.org/10.3386/w25349

Faircloth, B. S., \& Hamm, J. V. (2005). Sense of belonging among high school students representing 4 ethnic groups. Journal of Youth and Adolescence, 34(4), 293-309.

Finn, J. D., Pannozzo, G. M., \& Achilles, C. M. (2003). The "Why’s” of Class Size: Student Behavior in Small Classes. Review of Educational Research, 73(3), 321-368. https://doi.org/10.3102/00346543073003321

Fisher, O., O’Donnell, S. C., \& Oyserman, D. (2017). Social class and identity-based motivation. Current Opinion in Psychology, 18, 61-66. 
Fisher, O., \& Oyserman, D. (2017). Assessing interpretations of experienced ease and difficulty as motivational constructs. In Motivation Science (Vol. 3, Issue 2, pp. 133-163). https://doi.org/10.1037/mot0000055

Fry, R., Kennedy, B., \& Funk, C. (2021, April 01). STEM Jobs See Uneven Progress in Increasing Gender, Racial and Ethnic Diversity. Retrieved from https://www.pewresearch.org/science/2021/04/01/stem-jobs-see-uneven-progress-in-increas ing-gender-racial-and-ethnic-diversity/

Hansen, M. (2014). Characteristics of schools successful in STEM: Evidence from two states' longitudinal data. Journal of Educational Research, 107(5), 374-391. https://doi.org/10.1080/00220671.2013.823364

Hausmann, L. R., Ye, F., Schofield, J. W., \& Woods, R. L. (2009). Sense of belonging and persistence in White and African American first-year students. Research in Higher Education, 50(7), 649-669.

Heckman, J., \& Karapakula, G. (2019). Intergenerational and Intragenerational Externalities of the Perry Preschool Project. https://doi.org/10.3386/w25889

Howard, A. (2013). Learning privilege: Lessons of power and identity in affluent schooling. Routledge.

Hulleman, C. S., Godes, O., Hendricks, B. L., \& Harackiewicz, J. M. (2010). Enhancing interest and performance with a utility value intervention. In Journal of Educational Psychology (Vol. 102, Issue 4, pp. 880-895). https://doi.org/10.1037/a0019506

IJzerman, H., Lewis, N. A., Jr, Przybylski, A. K., Weinstein, N., DeBruine, L., Ritchie, S. J., Vazire, S., Forscher, P. S., Morey, R. D., Ivory, J. D., \& Anvari, F. (2020). Use caution when applying behavioural science to policy. Nature Human Behaviour, 4(11), 1092-1094. 
Jack, A. A. (2016). (No) Harm in Asking: Class, Acquired Cultural Capital, and Academic Engagement at an Elite University. Sociology of Education, 89(1), 1-19. https://doi.org/10.1177/0038040715614913

Jakobsen, J. C., Gluud, C., Wetterslev, J., \& Winkel, P. (2017). When and how should multiple imputation be used for handling missing data in randomised clinical trials - a practical guide with flowcharts. BMC Medical Research Methodology, 17(1), 162.

Kafai, Y. B., Lee, E., Searle, K., Fields, D., Kaplan, E., \& Lui, D. (2014). A crafts-oriented approach to computing in high school: Introducing computational concepts, practices, and perspectives with electronic textiles. ACM Transactions on Computing Education (TOCE), $14(1), 1-20$.

Kiefer, A. K., \& Sekaquaptewa, D. (2007). Implicit stereotypes and women's math performance: How implicit gender-math stereotypes influence women's susceptibility to stereotype threat. Journal of experimental social psychology, 43(5), 825-832.

Kizilcec, R. F., \& Kambhampaty, A. (2020). Identifying course characteristics associated with sociodemographic variation in enrollments across 159 online courses from 20 institutions. PloS One, 15(10), e0239766.

Kizilcec, R. F., Saltarelli, A., Bonfert-Taylor, P., Goudzwaard, M., Hamonic, E., \& Sharrock, R. (2020). Welcome to the Course: Early Social Cues Influence Women's Persistence in Computer Science. In Proceedings of the 2020 CHI Conference on Human Factors in Computing Systems. https://doi.org/10.1145/3313831.3376752

Kizilcec, R. F., \& Saltarelli, A. J. (2019). Psychologically Inclusive Design. In Proceedings of the 2019 CHI Conference on Human Factors in Computing Systems. https://doi.org/10.1145/3290605.3300704 
Kizilcec, R. F., Saltarelli, A. J., Reich, J., \& Cohen, G. L. (2017). Closing global achievement gaps in MOOCs. Science, 355(6322), 251-252.

Lareau, A. (2015). Cultural Knowledge and Social Inequality. American Sociological Review, 80(1), 1-27. https://doi.org/10.1177/0003122414565814

Lewis, N. A., Jr, \& Yates, J. F. (2019). Preparing Disadvantaged Students for Success in College: Lessons Learned From the Preparation Initiative. Perspectives on Psychological Science: A Journal of the Association for Psychological Science, 14(1), 54-59.

Lewis, N. A., Jr. (in press). Can we achieve "equality" when we have different understandings of its meaning? How contexts and identities shape the pursuit of egalitarian goals. Psychological Inquiry.

Loeb, S., Darling-Hammond, L., \& Luczak, J. (2005). How teaching conditions predict teacher turnover in California schools. Peabody journal of education, 80(3), 44-70.

Lord, S. M., Layton, R. A., \& Ohland, M. W. (2011). Trajectories of Electrical Engineering and Computer Engineering Students by Race and Gender. In IEEE Transactions on Education (Vol. 54, Issue 4, pp. 610-618). https://doi.org/10.1109/te.2010.2100398

Manly, C. A., \& Wells, R. S. (2015). Reporting the Use of Multiple Imputation for Missing Data in Higher Education Research. In Research in Higher Education (Vol. 56, Issue 4, pp. 397-409). https://doi.org/10.1007/s11162-014-9344-9

Master, A., Cheryan, S., \& Meltzoff, A. N. (2016). Computing whether she belongs: Stereotypes undermine girls' interest and sense of belonging in computer science. In Journal of Educational Psychology (Vol. 108, Issue 3, pp. 424-437). https://doi.org/10.1037/edu0000061

Makarova, E., Aeschlimann, B., \& Herzog, W. (2019). The Gender Gap in STEM Fields: The 
Impact of the Gender Stereotype of Math and Science on Secondary Students' Career Aspirations. Frontiers in Education, 4(July). https://doi.org/10.3389/feduc.2019.00060

Miller-Cotto, D., \& Lewis, N. A. (2020). Am I a “Math Person”? How Classroom Cultures Shape Math Identity Among Black and Latinx Students. https://doi.org/10.31219/osf.io/hcqst

Moody, J. (2021, April 27). Where the best public high schools are located. U.S. News \& World Report. https://www.usnews.com/education/best-high-schools/articles/where-the-best-public-high-s chools-are-located.

Murphy, M. C., Steele, C. M., \& Gross, J. J. (2007). Signaling threat: how situational cues affect women in math, science, and engineering settings. Psychological Science, 18(10), 879-885.

Nosek, B. A., Banaji, M. R., \& Greenwald, A. G. (2002). Math= male, me= female, therefore math $\neq$ me. Journal of personality and social psychology, 83(1), 44.

O’Brien, L. T., Garcia, D. M., Adams, G., Villalobos, J. G., Hammer, E., \& Gilbert, P. (2015). The threat of sexism in a STEM educational setting: The moderating impacts of ethnicity and legitimacy beliefs on test performance. Social Psychology of Education, 18(4), $667-684$.

O'Keeffe, P. (2013). A sense of belonging: Improving student retention. College Student Journal, 47(4), 605-613.

O’Neil, C. (2016). Weapons of Math Destruction: How Big Data Increases Inequality and Threatens Democracy. Broadway Books.

Oyserman, D., \& Lewis, N. A. (2017). Seeing the Destination AND the Path: Using Identity-Based Motivation to Understand and Reduce Racial Disparities in Academic Achievement. In Social Issues and Policy Review (Vol. 11, Issue 1, pp. 159-194). 
https://doi.org/10.1111/sipr.12030

Oyserman, D., Lewis, N. A., Yan, V. X., Fisher, O., Casey O’Donnell, S., \& Horowitz, E. (2017).

An Identity-Based Motivation Framework for Self-Regulation. In Psychological Inquiry

(Vol. 28, Issues 2-3, pp. 139-147). https://doi.org/10.1080/1047840x.2017.1337406

Peugh, J. L., \& Enders, C. K. (2004). Missing Data in Educational Research: A Review of

Reporting Practices and Suggestions for Improvement. In Review of Educational Research

(Vol. 74, Issue 4, pp. 525-556). https://doi.org/10.3102/00346543074004525

Price, J. (2010). The effect of instructor race and gender on student persistence in STEM fields.

Economics of Education Review, 29(6), 901-910.

Ray, V. (2019). A Theory of Racialized Organizations. In American Sociological Review (Vol.

84, Issue 1, pp. 26-53). https://doi.org/10.1177/0003122418822335

Rubin, D. B. (2009). Multiple Imputation for Nonresponse in Surveys. John Wiley \& Sons.

Using more inclusive language at Code.org. (n.d.). Retrieved May 31, 2021, from

https://support.code.org/hc/en-us/articles/360050257191-Using-more-inclusive-language-atCode-org

Russell, L. (2017). Can learning communities boost success of women and minorities in STEM? Evidence from the Massachusetts Institute of Technology. Economics of Education Review, 61(August), 98-111. https://doi.org/10.1016/j.econedurev.2017.10.008

Shih, M., Ambady, N., Richeson, J. A., Fujita, K., \& Gray, H. M. (2002). Stereotype performance boosts: The impact of self-relevance and the manner of stereotype activation. Journal of Personality \& Social Psychology, 83, 638-647.

Spencer, S. J., Steele, C. M., \& Quinn, D. M. (1999). Stereotype threat and women's math performance. Journal of experimental social psychology, 35(1), 4-28. 
Swan, S., \& Wyer Jr, R. S. (1997). Gender stereotypes and social identity: How being in the minority affects judgments of self and others. Personality and Social Psychology Bulletin, 23(12), 1265-1276.

U.S. Department of Education, Institute of Education Sciences, National Center for Education Statistics, National Assessment of Educational Progress (NAEP). (2018). Mathematics Assessments [Data file]. Retrieved from https://nces.ed.gov/pubs2018/2018052/tables/table_04.asp

Walton, G. M., \& Cohen, G. L. (2011). A brief social-belonging intervention improves academic and health outcomes of minority students. Science, 331(6023), 1447-1451.

Wang, J., Hong, H., Ravitz, J., \& Hejazi Moghadam, S. (2016, February). Landscape of K-12 computer science education in the US: Perceptions, access, and barriers. In Proceedings of the 47th ACM Technical Symposium on Computing Science Education (pp. 645-650).

Wilcox, P., Winn, S., \& Fyvie-Gauld, M. (2005). "It was nothing to do with the university, it was just the people": The role of social support in the first-year experience of higher education. Studies in Higher Education, 30(6), 707-722. https://doi.org/10.1080/03075070500340036

Yarger, L., Payton, F. C., \& Neupane, B. (2019). Algorithmic equity in the hiring of underrepresented IT job candidates. Online Information Review. 44 (2), p.383-395. https://doi.org/10.1108/OIR-10-2018-0334

Yeager, D. S., Hanselman, P., Walton, G. M., Murray, J. S., Crosnoe, R., Muller, C., Tipton, E., Schneider, B., Hulleman, C. S., Hinojosa, C. P., Paunesku, D., Romero, C., Flint, K., Roberts, A., Trott, J., Iachan, R., Buontempo, J., Yang, S. M., Carvalho, C. M., ... Dweck, C. S. (2019). A national experiment reveals where a growth mindset improves achievement. Nature, 573(7774), 364-369. 
Yeager, D. S., Walton, G. M., Brady, S. T., Akcinar, E. N., Paunesku, D., Keane, L., Kamentz, D., Ritter, G., Duckworth, A. L., Urstein, R., Gomez, E. M., Markus, H. R., Cohen, G. L., \& Dweck, C. S. (2016). Teaching a lay theory before college narrows achievement gaps at scale. Proceedings of the National Academy of Sciences of the United States of America, 113(24), E3341-E3348.

Zepeda, C. D., Martin, R. S., \& Butler, A. C. (2020). Motivational strategies to engage learners in desirable difficulties. Journal of Applied Research in Memory and Cognition, 9(4), 468-474. 


\section{Figures}

\section{Figure 1}

Schematic Representation of the Study Design

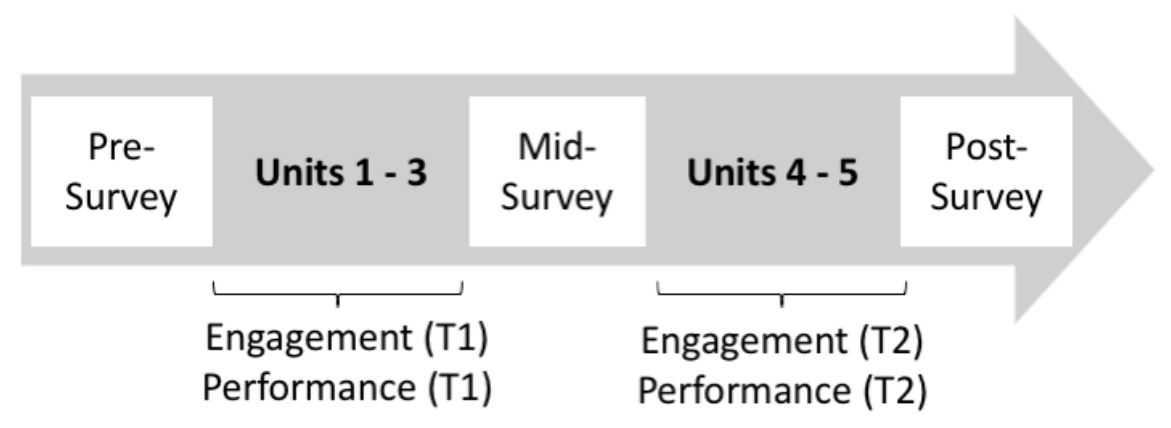




\section{Figure 2}

Class-level and School-level Moderators of the Effect of Student Mindsets on Engagement in the First Half of the Course

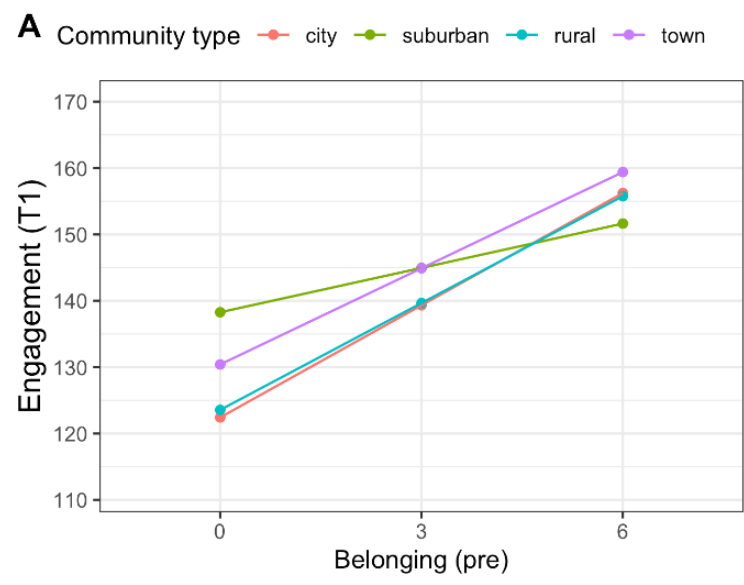

D Share of female students $\rightarrow 13 \% \rightarrow 29 \% \rightarrow 45 \%$

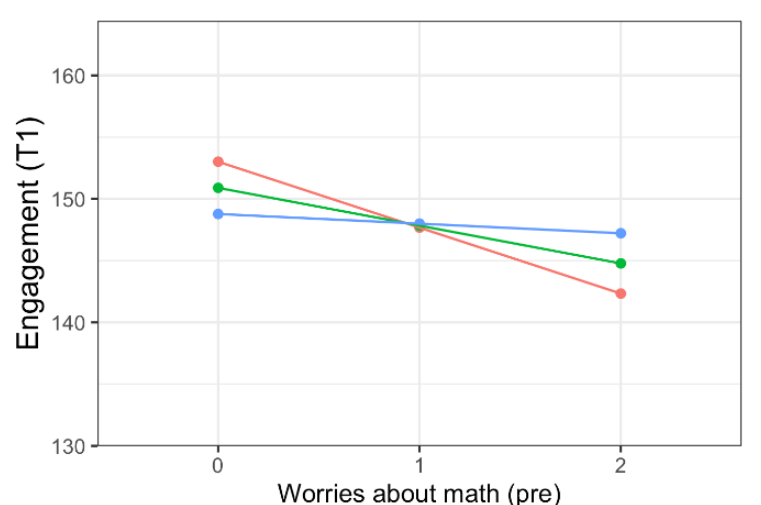
B Share of URM students $\rightarrow 1 \% \rightarrow 32 \% \rightarrow 62 \%$

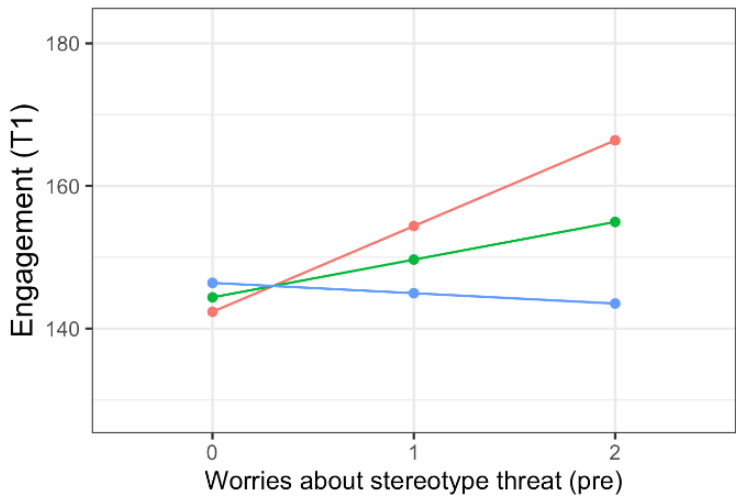

$\mathbf{E}$

Class size $\rightarrow 17 \rightarrow 26 \rightarrow 34$

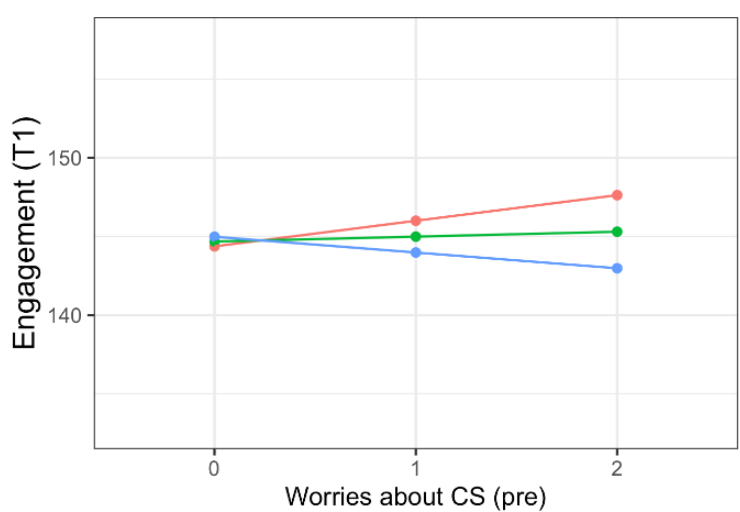

C Share of free lunch eligible $\rightarrow 5 \% \rightarrow 32 \% \rightarrow 59 \%$

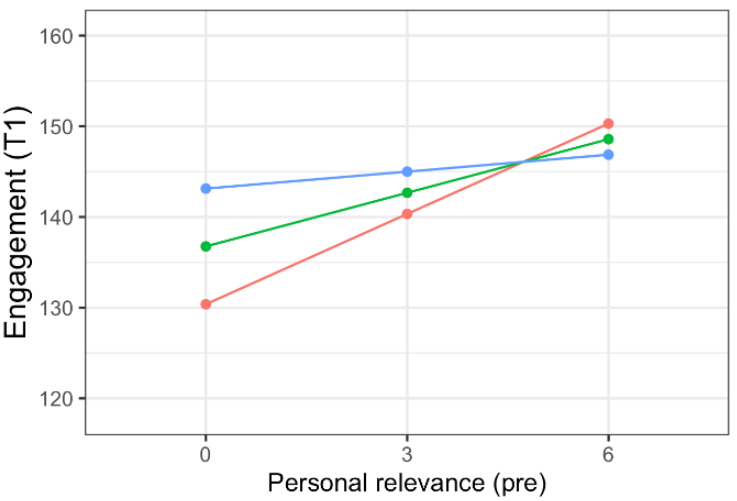

Personal relevance (pre)

Note. Point estimates were derived from a regression model with all main effects and moderators that were identified as important using stepwise variable selection. The values on the $\mathrm{x}$-axis represent the mean value and one standard deviation above/below the mean for each mindset $(0=$ Strongly disagree to $6=$ Strongly agree in panels $\mathrm{A}$ and $\mathrm{C} ; 0=$ Not at all, $1=A$ little, $2=A$ lot in panels $\mathrm{B}$, D, and $\mathrm{E})$. Each line represents the mean value and one standard deviation above/below the mean for each moderator variable. We chose female 
URM students in medium-sized rural schools with high school units as the baseline group to visualize these trends, but other baseline groups show similar trends. Panel A: The effect of belonging on engagement, moderated by community type. Panel B: The effect of stereotype threat on engagement, moderated by school URM proportion. Panel C: The effect of personal relevance on engagement, moderated by school free lunch proportion. Panel D: The effect of worries about math on engagement, moderated by class female proportion. Panel E: The effect of worries about CS on engagement, moderated by class size. 


\section{Table 1}

Sociodemographic Characteristics and Missing Value Distribution for Students in the Focal and Full Dataset

\begin{tabular}{|c|c|c|c|c|}
\hline \multirow[b]{2}{*}{ Characteristic } & \multicolumn{2}{|c|}{ Focal Dataset } & \multicolumn{2}{|l|}{ Full Dataset } \\
\hline & Distribution & $\begin{array}{c}\text { Missing Values } \\
(\%)\end{array}$ & $n$ (Distribution \%) & $\begin{array}{c}\text { Missing } \\
\text { Values (\%) }\end{array}$ \\
\hline Student-level & 7,142 students & & 106,443 students & \\
\hline URM status & & 34.32 & & 52.54 \\
\hline non-URM & $n=2,899(61.80 \%)$ & & $29,106(57.62)$ & \\
\hline URM & $\mathrm{n}=1,791(38.20)$ & & $21,408(42.38)$ & \\
\hline Gender & & 8.09 & & 17.89 \\
\hline Male & $\mathrm{n}=4,676(71.24)$ & & $60,138(68.18)$ & \\
\hline Female & $\mathrm{n}=1,888(28.76)$ & & $27,262(31.19)$ & \\
\hline Age & $M=16.19, S D=.88$ & 11.93 & $M=16.13, S D=.90$ & 32.15 \\
\hline Teacher-level & 247 teachers & & 6,105 teachers & \\
\hline URM status & & 97.33 & & 98.61 \\
\hline non-URM & $\mathrm{n}=89(46.60)$ & & $928(62.66)$ & \\
\hline URM & $\mathrm{n}=101(53.40)$ & & $553(37.34)$ & \\
\hline Gender & & 82.36 & & 88.80 \\
\hline Male & $\mathrm{n}=661(51.46)$ & & $6,687(56.09)$ & \\
\hline Female & $\mathrm{n}=599(47.54)$ & & $5,235(43.91)$ & \\
\hline Training & & 0.00 & & 1.04 \\
\hline Yes & $\mathrm{n}=4,926(69.0)$ & & & \\
\hline No & $\mathrm{n}=2,224(31.0)$ & & & \\
\hline Classroom-level & 364 classrooms & & 11,678 classrooms & \\
\hline URM proportion & $M=0.38, S D=0.30$ & 0.00 & $M=0.42, S D=0.33$ & 14.71 \\
\hline Female proportion & $M=0.29, S D=0.16$ & 0.00 & $M=0.31, S D=0.23$ & 4.87 \\
\hline Class size & $M=26.5, S D=8.6$ & 0.00 & $M=29.98, S D=91.43$ & 0 \\
\hline School-level data & 227 schools & & 3,242 schools & \\
\hline URM student proportion & $M=0.31, S D=0.30$ & 16.73 & $M=0.34, S D=0.30$ & 32.75 \\
\hline
\end{tabular}




\begin{tabular}{|c|c|c|c|c|}
\hline Free lunch recipient proportion & $M=0.33, S D=0.27$ & 17.53 & $M=0.34, S D=0.27$ & 33.29 \\
\hline Presence of highschool unit & $M=1.98, S D=0.13$ & 13.76 & $M=0.77, S D=0.42$ & 5.21 \\
\hline School size bin & & 15.57 & & 31.73 \\
\hline$(0,500)$ & $\mathrm{n}=617(10.23)$ & & $11,646(16.03)$ & \\
\hline$[500,1000)$ & $\mathrm{n}=1,096(18.18)$ & & $15,859(21.82)$ & \\
\hline$[1000,1500)$ & $\mathrm{n}=1,115(18.49)$ & & $14,396(19.81)$ & \\
\hline$[1500,2000)$ & $\mathrm{n}=1,300(21.56)$ & & $12,103(16.66)$ & \\
\hline$[2000,2500)$ & $\mathrm{n}=818(13.57)$ & & $9,790(13.47)$ & \\
\hline$[2500,3000)$ & $\mathrm{n}=580(9.62)$ & & $5,069(6.98)$ & \\
\hline$[3000,3500)$ & $\mathrm{n}=471(7.81)$ & & $3,288(4.52)$ & \\
\hline$[3500]$, & $\mathrm{n}=33(0.55)$ & & $515(0.71)$ & \\
\hline Community type & & 13.51 & & 30.46 \\
\hline City & $\mathrm{n}=1,954(31.6)$ & & $24,659(33.32)$ & \\
\hline Suburban & $\mathrm{n}=3,172(10.3)$ & & $31,755(42.90)$ & \\
\hline Town & $\mathrm{n}=416(51.4)$ & & $5,976(8.07)$ & \\
\hline Rural & $\mathrm{n}=635(6.7)$ & & $11,627(15.71)$ & \\
\hline
\end{tabular}

Note. The table summarizes the focal dataset prior to imputation. Distribution \% was calculated within the available data. The URM status data were provided by code.org. URM students consisted of White and Asian students. 
Table 2

Pooled Regression Coefficients of Mindset variables on Engagement at Time 1

\begin{tabular}{lr}
\hline & Engagement $(\mathrm{T} 1)$ \\
\hline Intercept & $125.14^{* * *}$ \\
& $(18.87)$ \\
Belonging & .76 \\
& $(.59)$ \\
Personal relevance & $1.97^{* * *}$ \\
& $(.40)$ \\
Stereotype threat & $-3.36^{*}$ \\
& $(1.39)$ \\
Worries about math & $-5.12^{* * *}$ \\
& $(.71)$ \\
Worries about CS & $1.51^{*}$ \\
Innate ability & $(.64)$ \\
& $.84^{* *}$ \\
Universal ability & $(.32)$ \\
Student age & -.42 \\
Student female & $(.35)$ \\
Student URM & -1.03 \\
Student female $\times$ URM & $(.54)$ \\
Sample size & \\
&
\end{tabular}

${ }^{*} p<.05, * * p<.01, * * * \mathrm{p}<.001$. 
Table 3

Pooled Regression Coefficients of Student Gender and URM on Mindsets

\begin{tabular}{|c|c|c|c|c|c|c|c|}
\hline & Belonging & $\begin{array}{l}\text { Personal } \\
\text { Relevance }\end{array}$ & $\begin{array}{c}\text { Stereotype } \\
\text { Threat }\end{array}$ & $\begin{array}{c}\text { Worries about } \\
\text { Math }\end{array}$ & $\begin{array}{c}\text { Worries } \\
\text { about CS }\end{array}$ & $\begin{array}{l}\text { Innate } \\
\text { Ability }\end{array}$ & $\begin{array}{c}\text { Universal } \\
\text { Ability }\end{array}$ \\
\hline \multirow[t]{2}{*}{ Intercept } & $4.54^{* * *}$ & $4.92^{* * *}$ & .03 & .32 & $.67^{* *}$ & $1.22^{* * *}$ & .64 \\
\hline & $(.23)$ & $(.31)$ & $(.09)$ & $(.17)$ & (.19) & $(.37)$ & $(.34)$ \\
\hline \multirow[t]{2}{*}{ Student Female } & $-.37^{* * * *}$ & $.33^{* * *}$ & $-1.00^{* * *}$ & $.14^{* * *}$ & $.42^{* * *}$ & .08 & $-.26^{* * *}$ \\
\hline & $(.03)$ & $(.04)$ & $(.01)$ & $(.03)$ & $(.03)$ & $(.05)$ & $(.05)$ \\
\hline \multirow[t]{2}{*}{ Student URM } & $-.09^{* * *}$ & $-.14^{*}$ & .03 & $.07^{*}$ & .06 & -.08 & -.05 \\
\hline & $(.04)$ & $(.05)$ & $(.02)$ & $(.02)$ & $(.03)$ & $(.09)$ & $(.07)$ \\
\hline \multicolumn{8}{|l|}{ Student Male $X$} \\
\hline \multirow[t]{2}{*}{ URM } & .08 & -.03 & .03 & .07 & -.03 & -.02 & .06 \\
\hline & $(.05)$ & $(.02)$ & $(.02)$ & $(.04)$ & $(.05)$ & .09 & $(.09)$ \\
\hline Class covariates & & & & & not & & \\
\hline School covariates & not included & not included & not included & not included & $\begin{array}{r}\text { included } \\
\text { not }\end{array}$ & not included & not included \\
\hline Teacher fixed effect & $\begin{array}{r}\text { not included } \\
\text { included }\end{array}$ & $\begin{array}{r}\text { not included } \\
\text { included }\end{array}$ & $\begin{array}{r}\text { not included } \\
\text { included }\end{array}$ & $\begin{array}{r}\text { not included } \\
\text { included }\end{array}$ & $\begin{array}{l}\text { included } \\
\text { included }\end{array}$ & $\begin{array}{r}\text { not included } \\
\text { included }\end{array}$ & $\begin{array}{l}\text { not included } \\
\text { included }\end{array}$ \\
\hline Sample size & 7,142 & 7,142 & 7,142 & 7,142 & 7,142 & 7,142 & 7,142 \\
\hline $\mathrm{R}^{2}$ & .23 & .22 & .07 & .08 & .12 & .14 & .23 \\
\hline Adj. $R^{2}$ & .20 & .19 & .04 & .05 & .08 & .10 & .21 \\
\hline
\end{tabular}

${ }^{*} p<.05, * * p<.01, * * * \mathrm{p}<.001$. 


\section{Appendix A}

Overview of Student Mindset Survey Items

\begin{tabular}{|c|c|}
\hline Construct & Items (mid-survey phrasing) \\
\hline $\begin{array}{l}\text { Social } \\
\text { belonging* }\end{array}$ & $\begin{array}{l}\text { I like this computer science class. } \\
\text { I feel comfortable in this computer science class. } \\
\text { Sometimes I feel unsure whether I belong in this class. } \\
\text { I am treated with as much respect as other students in this computer science class. } \\
\text { I feel like I can be myself in this computer science class. } \\
\text { I feel like my opinions are taken seriously in this computer science class. } \\
\text { It has been hard for people like me to be accepted in this computer science class. } \\
\text { I worry that the teacher or students in this class think that I am not as good at computer science as other students. }\end{array}$ \\
\hline $\begin{array}{l}\text { Stereotype } \\
\text { threat** }\end{array}$ & $\begin{array}{l}\text { I worry because of my gender. } \\
\text { I worry because of my race/ethnicity. }\end{array}$ \\
\hline $\begin{array}{l}\text { Personal } \\
\text { relevance* }\end{array}$ & $\begin{array}{l}\text { Computer science is important for my future. } \\
\text { I expect that I will use computer science in my job. } \\
\text { I want to take more computer science classes in the future. }\end{array}$ \\
\hline $\begin{array}{l}\text { Worries about } \\
\text { math** }\end{array}$ & I worry because I'm not good at math. \\
\hline
\end{tabular}

Innate ability* Some people are just better at learning and doing computer science than others.

Universal Every person has the same ability to learn computer science, no matter what their gender, skin color, or ability* background.

* seven-point scale ** three-point scale 


\section{Appendix B}

Pooled Pearson Correlation Matrix for Mindset and Outcome Variables

\begin{tabular}{|c|c|c|c|c|c|c|c|c|c|c|c|c|c|c|c|c|c|c|c|c|c|c|c|c|c|c|}
\hline & $\mathrm{M}$ & SD & 1 & 2 & 3 & 4 & 5 & 6 & 7 & 8 & 9 & 10 & 11 & 12 & 13 & 14 & 15 & 16 & 17 & 18 & 19 & 20 & 21 & 22 & 23 & 24 \\
\hline 1 pre-belonging & 4.22 & 0.94 & 0.83 & & & & & & & & & & & & & & & & & & & & & & & \\
\hline 2 pre-personal relevance & 4.47 & 1.28 & $0.43^{\mathrm{b}}$ & 0.90 & & & & & & & & & & & & & & & & & & & & & & \\
\hline 3 pre-stereotype threat & 0.10 & 0.32 & $-0.19^{b}$ & -0.02 & 0.66 & & & & & & & & & & & & & & & & & & & & & \\
\hline 4 pre-worries about math & 0.43 & 0.64 & $-0.23^{b}$ & $-0.07^{b}$ & $0.12^{\mathrm{b}}$ & - & & & & & & & & & & & & & & & & & & & & \\
\hline 5 pre-worries about CS & 0.80 & 0.73 & $-0.29^{b}$ & $-0.19^{b}$ & $0.07^{\mathrm{b}}$ & $0.26^{b}$ & - & & & & & & & & & & & & & & & & & & & \\
\hline 6 pre-universal ability & 0.86 & 1.43 & $-0.35^{b}$ & $-0.28^{b}$ & $0.08^{\mathrm{b}}$ & -0.003 & -0.02 & - & & & & & & & & & & & & & & & & & & \\
\hline 7 pre-innate ability & 1.61 & 1.45 & $-0.08^{b}$ & $-0.13^{b}$ & -0.02 & $-0.06^{b}$ & $-0.08^{b}$ & $0.09^{b}$ & - & & & & & & & & & & & & & & & & & \\
\hline 8 mid-belonging & 4.36 & 1.01 & $0.43^{\mathrm{b}}$ & $0.18^{\mathrm{b}}$ & $-0.15^{b}$ & $-0.21^{b}$ & $-0.19^{b}$ & $-0.09^{b}$ & 0.02 & 0.84 & & & & & & & & & & & & & & & & \\
\hline 9 mid-relevance & 4.35 & 1.42 & $0.23^{\mathrm{b}}$ & $0.55^{b}$ & $-0.04^{b}$ & $-0.13^{b}$ & $-0.19^{b}$ & $-0.06^{\mathrm{b}}$ & 0.02 & $0.39^{\mathrm{b}}$ & 0.91 & & & & & & & & & & & & & & & \\
\hline 10 mid-stereotype threat & 0.13 & 0.4 & $-0.10^{b}$ & 0.01 & $0.32^{\mathrm{b}}$ & $0.07^{b}$ & $0.05^{\mathrm{b}}$ & $0.07^{\mathrm{b}}$ & -0.01 & $-0.24^{b}$ & $-0.03^{\mathrm{a}}$ & 0.81 & & & & & & & & & & & & & & \\
\hline 11 mid-worries about math & 0.40 & 0.64 & $-0.17^{b}$ & -0.02 & $0.09^{b}$ & $0.58^{\mathrm{b}}$ & $0.18^{\mathrm{b}}$ & -0.01 & $-0.05^{b}$ & $-0.25^{b}$ & $-0.08^{\mathrm{b}}$ & $0.23^{\mathrm{b}}$ & - & & & & & & & & & & & & & \\
\hline 12 mid-worries about CS & 0.64 & 0.72 & $-0.22^{\mathrm{b}}$ & $-0.12^{\mathrm{b}}$ & $0.09^{\mathrm{b}}$ & $0.25^{\mathrm{b}}$ & $0.48^{\mathrm{b}}$ & -0.01 & $-0.08^{b}$ & $-0.29^{b}$ & $-0.18^{b}$ & $0.18^{\mathrm{b}}$ & $0.37^{b}$ & - & & & & & & & & & & & & \\
\hline 13 mid-universal ability & 0.98 & 1.38 & $-0.11^{b}$ & $-0.10^{b}$ & $0.07^{\mathrm{b}}$ & 0.02 & -0.001 & $0.32^{\mathrm{b}}$ & $-0.04^{b}$ & $-0.27^{b}$ & $-0.25^{b}$ & $0.15^{\mathrm{b}}$ & 0.02 & 0.01 & - & & & & & & & & & & & \\
\hline 14 mid-innate ability & 1.56 & 1.43 & 0.02 & 0.001 & -0.02 & $-0.04^{b}$ & -0.02 & $-0.07^{b}$ & $0.36^{\mathrm{b}}$ & 0.01 & $-0.04^{\mathrm{a}}$ & 0.02 & $-0.04^{a}$ & $-0.09^{b}$ & 0.01 & - & & & & & & & & & & \\
\hline 15 post-belonging & 4.25 & 1.06 & $0.36^{\mathrm{b}}$ & $0.15^{\mathrm{b}}$ & $-0.18^{b}$ & $-0.21^{b}$ & $-0.17^{b}$ & $-0.09^{b}$ & $0.05^{\mathrm{b}}$ & $0.66^{\mathrm{b}}$ & $0.32^{\mathrm{b}}$ & $-0.18^{b}$ & $-0.21^{b}$ & $-0.23^{b}$ & $-0.21^{b}$ & 0.01 & 0.83 & & & & & & & & & \\
\hline 16 post-relevance & 4.16 & 1.56 & $0.18^{\mathrm{b}}$ & $0.47^{\mathrm{b}}$ & -0.02 & $-0.15^{b}$ & $-0.19^{b}$ & -0.02 & $0.07^{b}$ & $0.30^{\mathrm{b}}$ & $0.70^{\mathrm{b}}$ & -0.02 & $-0.08^{\mathrm{b}}$ & $-0.17^{b}$ & $-0.16^{b}$ & -0.001 & $0.40^{\mathrm{b}}$ & 0.91 & & & & & & & & \\
\hline 17 post-stereotype threat & 0.16 & 0.44 & $-0.10^{b}$ & 0.001 & $0.33^{\mathrm{b}}$ & $0.07^{b}$ & $0.06^{\mathrm{b}}$ & $0.09^{b}$ & -0.02 & $-0.21^{b}$ & -0.03 & $0.44^{b}$ & $0.14^{\mathrm{b}}$ & $0.14^{\mathrm{b}}$ & $0.11^{\mathrm{b}}$ & -0.002 & $-0.29^{b}$ & $-0.04^{b}$ & 0.81 & & & & & & & \\
\hline 18 post-worries about math & 0.43 & 0.66 & $-0.16^{b}$ & -0.02 & $0.09^{\mathrm{b}}$ & $0.50^{\mathrm{b}}$ & $0.16^{\mathrm{b}}$ & 0.01 & $-0.04^{\mathrm{a}}$ & $-0.22^{\mathrm{b}}$ & $-0.10^{\mathrm{b}}$ & $0.18^{\mathrm{b}}$ & $0.62^{\mathrm{b}}$ & $0.25^{\mathrm{b}}$ & 0.03 & -0.03 & $-0.26^{\mathrm{b}}$ & $-0.09^{b}$ & $0.26^{\mathrm{b}}$ & & & & & & & \\
\hline 19 post-worries about CS & 0.67 & 0.73 & $-0.21^{\mathrm{b}}$ & $-0.14^{b}$ & $0.09^{b}$ & $0.21^{\mathrm{b}}$ & $0.47^{\mathrm{b}}$ & -0.01 & $-0.08^{b}$ & $-0.25^{\mathrm{b}}$ & $-0.18^{\mathrm{b}}$ & $0.11^{\mathrm{b}}$ & $0.26^{\mathrm{b}}$ & $0.54^{\mathrm{b}}$ & 0.03 & $-0.06^{\mathrm{a}}$ & $-0.28^{\mathrm{b}}$ & $-0.17^{\mathrm{b}}$ & $0.19^{\mathrm{b}}$ & $0.34^{\mathrm{b}}$ & - & & & & & \\
\hline 20 post-universal ability & 1.07 & 1.48 & $-0.08^{b}$ & $-0.07^{\mathrm{b}}$ & $0.07^{\mathrm{a}}$ & 0.01 & -0.02 & $0.27^{\mathrm{b}}$ & $-0.06^{\mathrm{b}}$ & $-0.22^{b}$ & $-0.17^{\mathrm{b}}$ & $0.12^{\mathrm{b}}$ & 0.02 & -0.001 & $0.45^{\mathrm{b}}$ & -0.02 & $-0.32^{\mathrm{b}}$ & $-0.22^{\mathrm{b}}$ & $0.15^{\mathrm{b}}$ & 0.04 & -0.01 & & & & & \\
\hline 21 post-innate ability & 1.56 & 1.54 & -0.004 & $0.04^{\mathrm{a}}$ & -0.004 & -0.01 & -0.02 & $-0.08^{\mathrm{b}}$ & $0.34^{\mathrm{b}}$ & -0.04 & 0.004 & -0.01 & 0.01 & -0.03 & -0.02 & $0.44^{\mathrm{b}}$ & -0.01 & -0.01 & -0.03 & $-0.04^{b}$ & $-0.07^{b}$ & 0.01 & - & & & \\
\hline 22 engagement T1 & 146.79 & 56.22 & $0.04^{\mathrm{b}}$ & $0.06^{\mathrm{b}}$ & $-0.03^{\mathrm{a}}$ & $-0.07^{\mathrm{b}}$ & 0.01 & 0.01 & 0.01 & 0.03 & $0.07^{\mathrm{b}}$ & 0.01 & $-0.06^{\mathrm{b}}$ & -0.02 & 0.01 & $0.04^{\mathrm{a}}$ & $0.07^{\mathrm{b}}$ & $0.09^{\mathrm{b}}$ & -0.003 & $-0.07^{\mathrm{b}}$ & -0.004 & -0.03 & 0.02 & & & \\
\hline 23 performance $\mathrm{T} 1$ & 0.19 & 0.27 & $0.07^{\mathrm{b}}$ & $0.06^{\mathrm{b}}$ & -0.003 & $-0.12^{\mathrm{b}}$ & $-0.07^{\mathrm{b}}$ & $0.04^{\mathrm{b}}$ & $0.04^{\mathrm{a}}$ & $0.09^{\mathrm{b}}$ & $0.10^{\mathrm{b}}$ & -0.01 & $-0.11^{b}$ & $-0.08^{\mathrm{b}}$ & 0.02 & $0.05^{\mathrm{a}}$ & $0.11^{\mathrm{b}}$ & $0.12^{\mathrm{b}}$ & -0.01 & $-0.09^{b}$ & $-0.08^{b}$ & 0.03 & $0.07^{b}$ & $0.20^{\mathrm{b}}$ & & \\
\hline 24 engagement T2 & 203.93 & 99.64 & $0.01^{\mathrm{b}}$ & $0.08^{\mathrm{b}}$ & -0.01 & $-0.13^{b}$ & -0.01 & 0.02 & 0.02 & $0.09^{\mathrm{b}}$ & $0.14^{\mathrm{b}}$ & -0.01 & $-0.13^{b}$ & $-0.07^{b}$ & -0.02 & 0.02 & $0.12^{\mathrm{b}}$ & $0.13^{\mathrm{b}}$ & -0.01 & $-0.12^{\mathrm{b}}$ & $-0.04^{\mathrm{a}}$ & -0.02 & 0.01 & $0.42^{\mathrm{b}}$ & $0.20^{\mathrm{b}}$ & \\
\hline 25 performance T2 & 0.12 & 0.25 & 0.02 & $0.03^{\mathrm{a}}$ & -0.001 & $-0.10^{\mathrm{b}}$ & -0.02 & $0.04^{\mathrm{b}}$ & $0.04^{\mathrm{a}}$ & $0.08^{\mathrm{b}}$ & $0.08^{\mathrm{b}}$ & 0.01 & $-0.09^{b}$ & $-0.04^{\mathrm{a}}$ & -0.01 & $0.04^{\mathrm{b}}$ & $0.10^{\mathrm{b}}$ & $0.07^{\mathrm{b}}$ & -0.02 & $-0.08^{\mathrm{b}}$ & $-0.04^{b}$ & -0.02 & $0.04^{\mathrm{a}}$ & $0.11^{\mathrm{b}}$ & $0.17^{\mathrm{b}}$ & $0.31^{b}$ \\
\hline
\end{tabular}

Note. Values in diagonal are Cronbach's alphas where applicable. Correlation significance level: ${ }^{\mathrm{a}} \mathrm{p}<.05 .{ }^{\mathrm{b}} \mathrm{p}<.01$. 